https://doi.org/10.18485/bogoljub_stankovic.2018.ch13

811.161.1'374(038)

371.671:811.161.1

МАЈА ПАВЛОВИЋ-ШАЈТИНАЦ*

Универзитет за привреду и правосуђе

Правни факултет

\title{
ЛЕКСИКОГРАФСКА КОНЦЕПЦИЈА ШКОЛСКИХ РЕЧНИКА БОГОљУБА СТАНКОВИЋА
}

\begin{abstract}
Анализом елемената макро- и микроструктуре школских речника Б. Станковића указано је да аутор, примењујући диференцијални метод у представљању речничког материјала, корисницима пружа могућност стицања лексикографске компетенције кроз процес изучавања страног језика и овладавања продуктивним комуникативним способностима на свим нивоима
\end{abstract}

Кљуине речи: лексикографија, макроструктура, микроструктура, продуктивне комуникативне способности, лексикографска компетенција

\section{Maja Pavlović Šajtinac}

\section{THE LEXICOGRAFIC CONCEPTUALIZATION OF THE SCHOOL DICTIONARIES OF BOGOLJUB STANKOVIĆ}

An analysis of micro- and macrostructural elements of B. Stanković's school dictionaries demonstrates the author's use of the differential method in the presentation of dictionary materials as a means of enabling lexicographic competence and mastering productive communicative abilities at all planned levels.

Key words: lexicography, macrostructure, microstructure, productive communicative abilities, lexicographic competence

Професор Б. Станковић посветио је значајну пажњу како теоријским размишљањима тако и практичном раду у области лексикографије. Први речник руског језика објавио је 1979; потом су следила остала лексикографска дела, као и монографија Лексикоірафски оїлеgи (Станковић 1999) у којој аутор разматра конкретна лексикографска питања која се односе на „комуникативну функционалност речника” (Станковић 1999:

*majamaja5@gmail.com 
15). Речници професора Станковића намењени су у првом реду ученицима и студентима, мада године 1998. у његовој редакцији излази и велики Руско-срйски речник обима од око 55.000 речничких јединица, намењен свима који имају потребу или задатак да одгонетну значење руске речи и пронађу њен семантички еквивалент у српском језику.

За потребе овог рада анализирали смо школске речнике Б. Станковића и његову лексикографске концепције, која је по нашем мишљењу неопходна за даљи развој лексикографских истраживања руско-српског и српско-руског двојезичја.

Посматрање школских речника овог аутора поделили смо на две узајамно повезане целине разматрајући засебно како макроструктуру тако и микроструктуру његових речника.

\section{Макроструктура}

Макроструктуру речника посматрали смо као скуп елемената који чине „самостални систем који поседује унутрашње односе и сложену организацију" (Дубичинский 2008: 60) На овом нивоу сви речници овог аутора састоје се од предговора, објашњења у оквиру којих аутор даје и преглед скраћеница, вежби, кључа за вежбе, руско-српских и у неким случајевима српско-руских речника и различитих спискова који ученицима дају додатна знања из области односа руско-српске лексике.

\section{Предговори}

Предговори свих речника Б. Станковића садрже информације о општем принципу по којима су речници написани. Како сам аутор каже, његови речници су „по својој структури комплексни, а по функцији дидактички" (Станковић 1999: 124); другим речима, речничке одреднице снабдевене су морфолошким, синтаксичким, лексичким, фонетско-акценатским, правописним, фразеолошким и лингвокултуролошким информацијама. Истовремено, дата су и упутства за коришћење речника, као и вежбања, коментари и илустративни примери који подвлаче дидактичку природу његових речника. Кад је реч о критеријумима којима се руководио приликом рада на речницима, аутор наводи да су то „језичка системност, комуникативна неопходност и тематска обавезност" (Станковић 2004: 5).

Следећа информација која се даје у предговорима говори о томе коме је речник намењен. Наиме, три речника овог аутора намењена су ученицима основних школа - Речник рускоі језика: за основну школу (1979), Руско-срйски речник: за основну школу (1999) и Руско-срйски и срйско-руски речник: за основну школу (2004) - у којима аутор наводи да 
ови речници осим што обухватају лексику релевантну за вишегодишње учење руског језика, „омогућавају и перманентно обнављање и активирање лексике савладане у претходном периоду" (Станковић 1999: 6). Ученицима средњих школа намењени су Школски руско-срйскохрватиски речник: среgњи ниво учења (1983) и Руско-срйски и срйско-руски речник: за среgюу школу (2011) у чијем предговору аутор каже да га могу користити не само средњошколци и студенти већ и сви они који започињу са учењем руског језика. Ова чињеница наводи на мисао да лексикографски рад датог аутора обухвата читав процес учења руског језика у српској говорној средини, од основне преко средње школе до високошколских установа.

Аутор у предговорима потом наводи број речничких одредница у сваком од речника, који се креће од 3.000 до 10.000 у зависности од нивоа знања корисника. Кад је реч о принципу бирања одредница, аутор узима у обзир лексички минимум неопходан приликом развијања продуктивних комуникативних способности корисника, затим фреквентност употребе дате лексеме, и, што је по нашем мишљењу веома важно са лексикографске тачке гледишта, „контрастивност према српском језику" (Станковић 1999:124). Аутор у предговору сваког речника такође наводи његов тип и намену, те тако за Реиник рускої језика (1979) каже да служи развијању пре свега пасивних комуникативних способности, док рецимо Школски руско-срйскохрвайски речник (1983) и Руско-срйски и срйско-руски речник (2011) помажу и приликом развијања активних способности. Осим тога, у предговору својих речника аутор експлицитно указује начин семантизовања речничких одредница, односно принцип упућивања на диференцијалне карактеристике двају језика (графички знаци). На крају предговора, аутор наводи да даје и лексикографске вежбе које доприносе бољем коришћењу речника, као и „кључ” за њихово решавање.

\section{Објашњења}

Овај део свих речника Б. Станковића започиње прегледом руске азбуке. Наведена су штампана велика и мала слова са називима у руском језику, најчешће датим у четвртастим заградама [бэ], [īэ]. Пажњу привлачи и чињеница да аутор у Руско-срйском и срйско-руском речнику: за среgюу школу (2011) наводи и преглед српске азбуке, што представља још један пример лексикографског приступа у упућивању на разлике између два језика. Тако се указује и на податак да слова руске азбуке имају своје називе, док у српском језику називи ћириличних слова одсуствују у складу са реформаторским принципом „који је спровео Вук (Караџић) један глас (фонема) - један знак" (Младеновић 2010: 317). 
Затим следе обавештења о томе на који начин су речничке одреднице снабдевене лексикографском позадином, која укључује акценат речи и граматичке квалификаторе. У оквиру објашњења аутор наводи начин на који су графички издвојене илустрације речничких одредница које могу упућивати на разлике између два језика, као што су међујезички хомоними и пароними, или на глаголе кретања или лексеме са изразито другачијом лексичком спојивошћу. Тако у Реинику рускої језика (1979) ове изразе аутор издваја графичким знаком правоугаоника, док се у Руско-срйском речнику: за основну школу (1999) користи црни кружић.

Објашњења о врстама речи дата су „директно и индиректно” (Станковић 1988: VIII), односно граматички квалификатор врсте речи добијају заменице, бројеви, прилози, предлози, речце, именице и узвици, док именице, придеви и глаголи нису снабдевене овом врстом квалификатора. Аутор у складу са лексикографским правилима наводи да су именице и придеви дати у номинативу, глаголи у инфинитиву, као и да су све променљиве врсте речи вертикалном цртом подељене на променљиви и непроменљиви део речи. Од речника до речника број обавештења варира, тако да их у првом речнику из 1979. има 14, у Руско-срйском и срйско-руском речнику: за основну школу (2004) налазимо 27, док их у речнику за средњу школу из 2011. има 31. Аутор у речницима који садрже и српско-руски глосар, како наводи, даје минимална граматичка објашњења. Он указује на случајеве неподударања глаголских рекција и синтаксичке спојивости богато их илуструјући, а корисницима скреће пажњу како су са тачке гледишта двојезичне лексикографије решавана питања унутрашње полисемије, односно указује да су полисемична значења лексеме означена арапским бројевима као у случају лексеме му́фта 1. муф, 2. сиируи. спојница, спојка.

\section{Скраћенице}

Када је реч о скраћеницама, и њихов број се од речника до речника мења. Речник рускої језика: за основну школу (1979) садржи 33 скраћенице, Руско-срйски и срйско-руски речник: за основну школу (2004) 31, док Руско-срйски и срйско руски речник: за среgюу школу (2011) садржи чак 68 лексикографских техничких скраћеница. Аутор у циљу снабдевања својих речника „што бољом методологијом коришћења речника” (Дубичинский 2008:63) осим граматичких квалификатора или маркера тј. „лексикографских ознака које чине граматичке особености лексема као што су врста речи, род и број код именских речи, вид код глагола, падежне ознаке код флективних речи" (Ристић 2014: 113) као што су $а \kappa, \bar{\imath} e н, ~ м$, ж, несврщ,узв и др. уводи и функционално стилске свеи, офиน, фиі, разі,

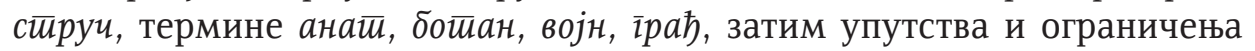


в, $y \bar{u}$, нейром, као и друштвено историјске маркере нар (народски) или засти. На принцип постепеног усложњавања презентовања лексикографског материјала у речницима за основну школу наилазимо и на нивоу граматичких квалификатора; када је рецимо о глаголима реч видимо две информације - несврш и сврш - док их је у речнику за средњу школу свих шест, јер су додати називи глаголских времена имй, uнф, $\bar{u} е р \phi$, као и назив функције у реченици йpeguк. Иста је ситуација и са квалификаторима који се односе на функционалне стилове или друштвено историјске квалификаторе као што су засти, нароgски.

\section{Вежбе}

Полазећи од основне намене школских речника, односно идеје да им је задатак да „пруже регистар значења речи (лексичко-семантичких варијанти) актуелних за дати ниво и профил презентираних путем навођења преводних еквивалената" (Кончаревић 2004: 248) аутор у свој речнике укључује речничка вежбања. Као и на претходним нивоима конципирања речника, аутор прати принцип постепеног усложњавања и градуалности по коме „постепено усложњавање стоји у директном односу са комплексношћу лексикографског описа, која је оријентисана на обраду речничког чланка са свих аспеката релевантих за дати, програмом предвиђени, ниво учења језика" (Пипер 1992: 21) те тако спектар вежби зависи од нивоа претпостављеног знања. Другим речима, у речнику из 1979. намењеном ученицима основне школе аутор даје 14 вежбања, у речнику из 1999. такође намењеном ученицима основне школе, али средњег степена учења 60 вежбања, док их у речнику за средњу школу има 80. Укажимо на нека од вежбања као што су: овладавање вештином одређивања морфолошког облика речи у два језика, утврђивање граматичких категорија рода код именица, одређивање појединих падежних облика, рецимо генитива једнине именица (неgеля, отgел, помещение) или локатива једнине једносложних именица (боц̆, бок, рот), утврђивање садашњег и будућег времена појединих глагола (болеть, готовиться, мыть), овладавање вештином идентификовања облика singularia i pluralia tantum ( gеньги, коренья, санки), овладавање вештином распознавања глаголске рекције и међујезичког поређења (болеть, вспомнить, готовиться), као и употребе истих предлога са различитим падежима у два језика као што су рецимо предлози по, $c$, за, овладавање вештином разумевања и правилног превођења са руског на српски и са српског на руски језик међујезичких хомонима (банка, баня, буква, винограg) или овладавање вештином правилног коришћења глагола кретања у руском језику (ехать/езguть, бегать/бежать). 
Као што се види, вежбања су конципирана тако да активирају и рецептивне и продуктивне способности ученика. После вежбања, у већини случајева дати су и правилни одговори на питања, на основу чега можемо закључити да ове вежбе представљају дидактичку смерницу ка изучавању руског језика и умногоме обогаћују вредност школских речника овога аутора.

\section{Тематски чланци и спискови}

Специфичност речника Б. Станковића предстаљају и тематски чланци које аутор уноси у све своје речнике. Тако рецимо у првом речнику он даје пет тема (Имена народа, Географска имена, Имена и презимена, Скраћено писање неких од најчешћих речи, Преглед међујезичких хомонима и паронима), у Школском руско-срйскохрвайском речнику (1983) налазимо четири теме (Списак суфикса, Скраћенице у стручним текстовима, Међународни систем јединица и Списак транслитеризованих руских речи латиницом). Руско-срйски и срйско руски речник: за основну школу (2004) снабдевен је са десет тематских чланака (Аутомобилски туризам, Боја, Воће, Гранични прелаз, Здравствена заштита, Јеловник, Обућа (продавница обуће), Поздрави, Цвеће, Честитања), док у Руско-срйском и срискко-руском речнику: за среgюу школу (2011) налазимо тридесет тематских чланака, уз свако слово азбуке (На аеродрому, У апотеци, На (моторном) броду, у возу, На граничном прелазу, У дому здравља, Екскурзија по граду и др.).

Основна вредност ових тематских чланака је, по нашем мишљењу, развијање комуникативних способности ученика као и приближавање понекад једноличног лексикографског текста живом разговорном језику. Истовремено, пратећи диференцијални метод, аутор у овим тематским чланицима и списковима особиту пажњу посвећује упозоравању на могућу интерференцију у различитим областима комуникативне делатности као што су писање великих и малих слова код назива народа, разлике у граматичком броју или у транспоновању неких страних топонима, као рецимо Атина/Афинь, писање и изговор иницијалног гласа у неким случајевима, као у примеру типа Хамбург/Гамбург, или разлике у графичким облицима истих имена у два језика, као у случајевима Ђорђе/Джоряже или Маја/Майя. Такође аутор указује на различито обележавање скраћеница, као што су $u \bar{u} . g$. у руском и итд. у српском, или напр. / нпр. Подвуцимо и да су прегледно графички приказана питања међујезичка хомонимије, наиме сви делови дуплог међујезичког пара дати су у једном реду, као у примеру: ВИНОГРАД - грожђе : виноград - ВИНОГРАДНИК, као и на важност списка суфикса који је дат у Рускосрйском и срйско-руском речнику: за среgюу школу (2011), а чији је циљ 
како аутор каже „да помогне у откривању значења речи којих нема у основном корпусу" (Станковић 2011: 11).

\section{Илустрације}

Неки од речника овог аутора садрже и „илустрације чији задатак није само да покажу спољашњи изглед предмета, већ и да укажу на његов смисао" (Тюрина 2004: 158). Тако рецимо у Руско-срйском и срйскоруском речнику: за основну школу из 2004. аутор скоро на свакој страни нуди цртеже који подвлаче значење одреднице, мада има и страница које су опремљене само илустрацијама без лексикографског текста, као што су оне на којима је мапа московског метроа, дивље животиње, поврће, одећа, воће или људско тело. Аутор даје графичке илустрације за лексеме које, најчешће због могуће интерференције, могу отежати процес учења. Тако у српско-руском делу налазимо 171 графички приказ и фотографију којима су илустроване лексеме као што су табла, стена, снешко белић, слушалица, рукавица, риболов, радијатор, јагода, прст, једноспратна кућа, станица; фотографије пак илуструју културно-историјске споменике и симболе Србије, као што су зграде Скупштине, Народног позоришта, Народног музеја, Деканата београдског универзитета, затим споменика Победнику, зграде хотела Москва, која осим што је једна од лепших у Београду, представља и симбол културно-историјских веза два народа и др. Избор ових илустрација говори о томе да је речник намењен и ученицима руског говорног подручја који уче српски језик. Томе у прилог сведоче и неке језичке илустрације одредница овог дела речника као што је објашњење лексеме смоква - инжи́p м; На Бадње вече код нас је обичај да се једу суве смокве. Ве́чером накану́не Рожgества́ у нас в обычае (или при́нято) есть сушённьй инжи́р, или називи верских празника Божић - Рожgество́, Ускрс - Па́сха, слава - семе́йный пра́зgник. Можемо рећи да илустрације у речницима Б. Станковића имају изразито едукативно функцију, а сем тога утичу и на живљу перцепцију лексикографског материјала и стимулаццију говорне компетенције ученика.

\section{Микроструктура}

Под микроструктуром речника посматрали смо питања везана за конструкцију речничког чланка, као одвојеног система на више нивоа који подразумева фонетске, граматичке, семантичке, употребне, стилске, илустративне и друге информације о речничкој јединици.

Речничка одредница у речницима Б. Станковића дата је великим штампаним словима, одреднице су сложене двостубично, променљи- 
ве врсте речи подељене су усправном цртом на непроменљиви и променљиви део речи.

\section{Фонетско-акценатски ниво}

Све одреднице у речницима су акцентоване; указано је на померање акцента у падежним и множинским облицима као у примеру именице (зим|á, -bl', aк. зи́мy, мн. -ы, зим,) или у парадигматским облицима глагола (воgúl|ür, вожý, во́guщъ, во́gя⿻ü).

\section{Граматички ниво}

Кад је реч о граматичком нивоу, осим указивања на лексикографску обраду променљивих и непроменљивих врста речи, пажњу смо задржали на начину на који аутор обрађује глаголе, односно указује на диференцијалне допуне појединих глагола, као и начину обраде предлога.

Аутор се како глаголском допуном тако и синтаксичком обрадом бави у више радова. Кад је реч о глаголским допунама или глаголској рекцији која се у једнојезичким речницима „наводи експлицитно онда када је њено постојање или одсуство услов за реализацију неког значења" (Марковић, 2014: 80) у двојезичним речницима, и то нарочито блискосродних језика какви су руски и српски, указивање на падежне допуне има пре свега дидактичку функцију, јер утиче на елиминацију могуће интерференције из матерњег на проучавани језик. Кад је реч о презентовању предлога, аутор анализом неких од претходних руско-српских речника долази до закључка да су предлози „непотпуно презентовани и неадекватно преводно семантизовани" (Станковић 1999: 111) јер се врши семантизација као и других врста речи. Аутор констатује чињеницу да су предлози функционалне речи чије лексичко значење представља „значење овог или оног односа” (Станковић 1999: 97).

Код именица аутор граматичким квалификаторима указује на род, а семантички еквивалент опремљен је овим квалификатором у случају диференцијације (крова́m|b ж кревет $\mathcal{M}$ ), осим номинатива указано је и на генитив једнине и номинатив и генитив множине, док остале падеже аутор наводи само у случају да по облику представљају изузетак или одређену тешкоћу за усвајање као у примеру лес м, леса́, л. о ле́се, в лесу́; мн. лесá, лесо́в. Код именица које имају само облик једнине или само облик множине даје се ограничавајући квалификатор једн. или мн. нема као у случају именице брюки мн. брюк, једн. нема. Такође у случају да именице не подлеже падежној промени аутор даје обавештење не мења се, као у примеру метро́ с (не мења се) - метро м.

Придеви се наводе у облику за мушки род, док аутор на облике осталих родова указује у загради, као и на облике за множину, како за 
дуже тако и за краће облике, као у примеру волше́бн|ъцй (-aя, -ое, -ъье; волше́б|ен, -на, -но, ны). На компаративни облик аутор скреће пажњу у оним случајевима у којима долази до промене основе, као у случају хоро́ший - лу́чше или плохо́й - ху́же.

Као посебне одреднице аутор обрађује прилоге настале од придева уколико су фреквентни или се не могу лако препознати, као рецимо прилог в вруг - прилог изненада, одједном.

Глаголе аутор наводи у инфинитиву, облике за прво и друго лице једнине и треће лице множине садашњег времена даје у загради, док иза заграде квалификатор вида указује на видску припадност као у примеру вбе|жáms (-гý, -жúшь, -гу́m) несврш. утрчати. Аутор ограничавајућим квалификаторима упозорава на случајеве у којима се 1. и 2. лице једнине не употребљавају, као у случају глагола возника́|mь (1. и 2. л. се не употреб., -ет, -ют) несврш. појављивати се. Облике перфекта аутор наводи за глаголе „који се у инфинитиву завршавају на -чь и који у садашњем (простом будућем) времену имају основу у 1. л једнине и 3. л множине и у прошлом времену на [к] или [г]" (Р. Маројевић 1983: 175) као у примеру печь (пеку́, печёщь, пекým; перф. пёк, пекла́). Када је о обради глагола реч, аутор посебну пажњу обраћа на разлике у глаголској рекцији између два језика. Употребом заменице или заменице и придева аутор указује на облик допуне глагола у једном и у другом језику, као у примеру глагола благоgap|úmь (-ю, -и́шь, -яm) несврш. кого́ за ито захваљивати коме на чему, који у руском језику има допуну у акузативу, док је у српском допуна у дативу. Неке од примера овакве ауторове обраде диференцијалних допуна глагола навешћемо у следећој табели:

\begin{tabular}{|c|c|}
\hline руски & српски \\
\hline БОЛЕ́ТЬ чем. Он боле́ет гри́ппом. & боловати og чеīa. Он болује од грипа. \\
\hline $\begin{array}{l}\text { ГОТО́ВИТЬСЯ к чему. Он готовиться } \\
\text { к экзамену. }\end{array}$ & $\begin{array}{l}\text { спремати се за шйо. Он се спрема } \\
\text { за испит. }\end{array}$ \\
\hline $\begin{array}{l}\text { ЖАЛЕ́ТЬ о ком-чем. Он жалеет о } \\
\text { товарище. }\end{array}$ & $\begin{array}{l}\text { жалити за кuм-чuм. Он жали за } \\
\text { другом. }\end{array}$ \\
\hline $\begin{array}{l}\text { ИЗМЕНИ'ТЬ Кому-чему. Он изменил } \\
\text { рояине. }\end{array}$ & 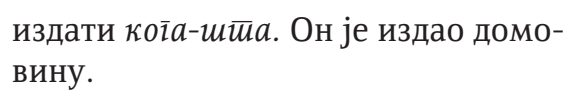 \\
\hline $\begin{array}{l}\text { НАБЛЮДА́ТЬ за кем-чем. Кто наблю- } \\
\text { gaem за gетьми? }\end{array}$ & $\begin{array}{l}\text { надгледати коі̄a-чеīa. Ко надгледа } \\
\text { децу? }\end{array}$ \\
\hline $\begin{array}{l}\text { ПРОСТИ'Ть кого за что. Учитель } \\
\text { простил ученика за опозяание. }\end{array}$ & $\begin{array}{l}\text { опростити коме за шй } а \text {. Наставник } \\
\text { је опростио ученику за закашњење. }\end{array}$ \\
\hline
\end{tabular}


Б. Станковић се овим питањем опширније бавио у тексту „О рекцијским разликама руских и српских глагола” објављеном у часопису Живи језици (Станковић 1974: 5-17) у коме наводи да диференцијалне разлике „представљају велики проблем у настави руског језика не само на основношколском и средњошколском нивоу, већ како је показано у радовима о настави руског језика код нас и на факултетском нивоу" (Станковић 1974: 5). Кад је реч, рецимо о руском глаголу болеть за који аутор у истом тексту наводи да припада групи „глагола општег значења боловања и физичког страдања" који се по својој синтаксичкој спојивости разликују од српских еквивалената, наиме у руском језику ови глаголи међу које спадају и заболеть, страgать, хворать, перехворать и сл. употребљавају се у конструкцији глагол+инструментал, док се њихови семантички еквиваленти у српском језику користе у конструкцијама глагол+предлог (од)+генитив. Пажњу привлачи и група глагола међу које спада глагол простить, којој припадају и глаголи благоgарumь, вовьблагоgарить, отблагоgарить, поздравлять, прощать, извинить, извинять и сл. који се у руском језику употребљавају у конструкцији глагол+акузатив, док се за српске еквиваленте користи конструкција глагол+датив. Међутим, како аутор наводи „историјски посматрано, ови руски глаголи су имали или су могли имати допуну у дативу, а што се види из примера: И станешь старости моей благоgарить (Ломоносов, Тамара и Селим)", на основу чега у истом тексту аутор закључује да је „савремено стање рекција руских глагола ове групе ново. Насупрот руским глаголима, спрскохрватски еквиваленти задржали су стару рекцију и тако је настала диференцијација" (Станковић 1974: 10).

Са дидактичке тачке гледишта, по речима Б. Станковића управо анализа диференцијалних односа даје објашњење појавама интерференције „при усвајању руских глагола и њихових синтаксичких спојивости” (Станковић 1974: 6). Када је реч о достизању позитивних резултата и елиминацији могуће интерференције, аутор скреће пажњу да се у наставном процесу особита пажња мора посветити овом питању. Ми бисмо додали да је задатак и школске лексикографије да се пажљиво бави овим питањем. Због тога, по нашем мишљењу, начин на који Б. Станковић врши лексикографску обраду глагола са различитом синтаксичком спојивошћу у својим школским речницима представља пример за углед.

Кад је реч о предлозима и њиховој обради, аутор указује на разлике у спојивости са падежима у два језика у тексту „Руски и српски предлози у речницима и настави" (Лексикоїрафски оїлеgu 1999: 97-109), и наводи да од 19 „руских предлога који имају у српском етимолошки идентичне еквиваленте, као што су без-без, gо-до, за-за, из-из, из-за-иза, из-поg-испод, к-к, межgy-међу, на-на, наg-над, o-о, от-од, переg-пред, no-по, nоg- 
под, nрu-при, pagu-ради, $c$-с, $y$-у, неподударање у спојивости примећује се код седам предлога и то код за, межgy, нag, nepeg, nо и с." (Станковић 1999: 99). Аутор даље наводи да се приликом лексикографске обраде „еквивалентност не успоставља на нивоу предлога као лексема, већ на нивоу конкретних значења исказаних предлошко-падежним конструкцијама" (Станковић 1999: 106). Пример лексикографске обраде ових предлога и њихових предлошко-падежних конструкција илустроваћемо обрадом предлога за:

За преgлог - I) с акузативом - 1. за+акузатив=за+акузатив: Они́ gе́ржатся за́ руки. Они се држе за руке. 2. кад означава правац а) зa+акузатив= за+акузатив: Маши́на зае́хала за́ угол. Ауто је скренуо за угао. Они́ се́ли за сто́л. Сели су за сто. б) за+акузатив=иза+генитив: Он стал за gе́рево. Стао је иза дрвета. 3. кад означава време: а) за+акузатив=за+акузатив. Он всё э' то cgе́лал за оgну́ неgе́лю. Све је то урадио за једну недељу. б) за+акузатив=пр еко+генитив: Емý за пятьgеся'mь лет. Он има преко педесет година. 4. кад означава циљ: за+акузатив=за+акузатив: Они́ боро́лись за свобо́gy. Борили су се за слободу. II) с инструменталом - 1. кад означава место: а) за+инс трументал=за+инструментал: Они́ сияя'm за столо́м. Они седе за столом. б) за+инструментал=иза+генитив: Ма̀льиuк стои́m за gе́ревом. Дечак стоји иза дрвета. 2. кад означава циљ: за+инструментал=по+акузатив: $Я$ ugý за лека́рством. Идем по лек.

Лексикографској обради предлога у двојезичним речницима Б. Станковић посвећује пажњу и у тексту „Предлози у будућем српскоруском речнику" (Лексикоірафски оїлеgu 1999: 111-122). Наиме, аутор у овом огледу указује на разлику у лексичко-синтаксичкој спојивости предлога полазећи од српског језика. Када је рецимо реч о већ разматраном предлогу за, како у наведеном чланку из Лексикоірафских оїлеga тако и у Руско-срйском и срйско-руском речнику речнику за среgюу школу (2011) Б. Станковић наводи у оквиру примера употребе овог предлога и његових семантичког-синтаксичких еквивалената у руском језику преко тридесет могућих језичких ситуација. Тако он дели употребу предлога $3 a$ на три велике групе: са генитивом у одредби времена, са акузативом у одредби правца и са инструменталом. Аутор упозорава да у првом случају еквивалент у руском језику може бити са предлозима в, во+локатив или акузатив, као и са предлогом при+локатив (за младости=в мо́лоgости или за живота мога оца=при жи́зни моего́ оти,á). Кад је реч о употреби предлога за+акузатив у српском језику у одредби времена, у руском језику могу постојати варијанте в, во, на, через и за+акузатив (позвати госте за суботу=пригласи́mь госте́й на суббо́ту, вратити се за један сат=верну́ться че́рез час). У одредби циља и намене 
српска синтагма за+акузатив може у руском језику бити транспонована предлозима gля, pagu+генитив, к+датив, за, про, на, в+акузатив (за општу ствар=págu óбщего gе́ла, поклонити за успомену=nоgápumь на па́мять, за казну=в наказа́ние)

Аутор дакле питању лексикографске обраде предлога у двојезичним руско-српским и српско-руским речницима приступа са синтаксичке тачке гледишта, односно путем „указивања на лексичко-синтаксичку спојивост" (Станковић 1999: 112), што са своје стране корисницима речника даје бољу могућност усвајања не само значења појединих предлога, већ и разумевање синтаксичке структуре посматраног језика.

\section{Семантички ниво}

Када је реч о садржају објашњења односно о лексичком значењу, задатак лексикографа у складу са теоријом лексикографије јесте да објасни „појам који је категорија мишљења, речју која је знак за тај појам и која истовремено јесте знак у језичком систему" (Тошовић 1992: 83).

Аутор у свим својим речницима користи пре свега метод преводне еквиваленције (клён - јавор, клен), као и метод описног превођења када у српском језику не постоји преводни еквивалент (кисе́ль - кисељ, воћни сируп укуван са кромпировим брашном) или наводи синонимске низове (клаgова́я - остава, складиште, магацин). Када је реч о илустрацији примера аутор у великом броју случајева користи устаљене изразе и пословице (игра́mь коме́gию - претварати се, клетчатая бумага - милиметарски папир, ему везёт - има среће; как ни кинь все клин - како год окренеш не ваља, всему́ своё вре́мя - све у своје време, коне́u, - ее́лу вене́u, конац дело краси), међутим основна вредност речника Б. Станковића по нашем мишљењу представља чињеница да аутор у примерима у којима је то могуће указује на лексичко-синтаксичку спојивост како када је реч о лексемема руског језика, тако и у случају лексема српског језика, као и на „разлике у лексичко-синтаксичкој спојивости у сложеном међуодносу руског и српског језика" (Станковић 2011: 7).

Аутор вршећи семантизацију појединих лексема лексикографски обрађује и случајеве унутрашње поделе значења одредница, односно полисемије, означавајући свако значење бројевима у оквиру истог речничког чланка на тај начин указујући и на „семе нижег ранга као релевантан елемент реализације значења" (Гортан-Премк 2014: 132), као у примеру: 
ПОПРА́В|КА (-ки,, мн. -ки, -ок)ж. 1. поправљање, поправак 2. коректура 3. опорављање, опоравак 4. допуна, амандман попра́вка к резолю'ции амандман (допуна) резолуцији

Језичке хомониме аутор даје у различитим речничким одредницама распорећеним у низу једна за другом и обележене бројевима као у примеру:

ПОСТ ${ }^{1}$ (-á, мн. -ы', -о́в) м пост, уздржавање од јела

ПОСТ² (-á, лок о посте́, на посту́, мн -ы', -о́в) м 1. стража; стражарско место стоя'ть на посту́ бити на стражи; наблюдательный пост осматрачница 2. дужност, положај занима́ть отве́тственный пост бити на одговорној дужности;

Питање међујезичке хомонимије аутор решава на тај начин што код сваке речничке одреднице која спада у ову групу језичких појава наводи упозоравајуће квалификаторе - не значи, види; а графичким знаком $(\bullet)$ указује на појаву међујезичке хомонимије и истовремено упућује корисника речника на руски облик датог хомонимског пара као у примерима: вре́gный - штетан • не значи вредан в. труgолюби́вый; полюби́ть заволети • не значи пољубити в. пощелова́ть. Уосталом, у једном од својих речника у оквиру тематских спискова аутор даје преглед најфреквентнијих хомонимских парова, што сведочи да се овом важном питању осим у настави руског језика на српском говорном подручју и у лексикографској делатности посвећује доста пажње.

Анализирајући школске речнике Б. Станковића можемо закључити да они прате „концепцију корисника коју чине циљ, намена, узимање у обзир узрасних специфичности корисника, њихов перцепцијски фон као и активну заинтересованост за предложени материјал" (Бытева 2010: 15). Додали бисмо да аутор у својим речницима такође узима у обзир и принципе конструисања школских речника (в. Павловић-Шајтинац 2017: 152-161) који подразумевају усаглашеност са потребама корисника, праћење линије постепеног и градуелног усложњавања материјала, узрочно-последични однос између двојезичне грађе и типа језичке структуре матерњег језика ученика, а нарочито бисмо указали на принцип диференцијалног метода у лексикографском приступу конципирања школских речника руског језика у српском говорном простору који аутор примењује на свим нивоима (фонетском, морфолошком, творбеном, синтаксичком, семантичком). По нашем мишљењу, речници овог аутора захваљујући пре свега јасним и прецизним објашњењима у уводном делу речника, као и садржајним објашњењима речничких одредница на више нивоа, омогућавају корисницима да стекну лекси- 
кографску компетенцију, која је по нашем мишљењу, незаобилазна у процесу учења страних језика.

На крају, навели бисмо мисао Н. Рацковића (2006: 245) која илуструје рад на речницима: „Лексикографски посао се одвија лагано и споро одмиче. То је посао за који треба доста времена; ...То је, могло би се рећи посао који се ради једном заувјек, а то искључује брзину. Без обзира на то што се наука брзо развија, што стално пристижу нови подаци, оно што је урађено (за период и област) остаје једном за свагда". Тако и речници професора Богољуба Станковића остају за свагда да утиру пут новим лексикографским напорима у руско-српском и српско-руском двојезичју.

\section{Цитирана литература}

Бытева Татьяна И. «К уточнению некоторых лексикографических понятий» Материалы секций XXXIX Международной филологической конференции 15-20 марта Санкт Петербург 2010, 9-16.

Гортан-Премк, Даринка. «Дефинисање у српској лексикографији» [B:] Рајна Драгићевић (ред.) Савремена српска лексикографија у теорији и пракси Београд: Чигоја 2014, 131-139.

Дубичинскй, Владимир В. Лексикография русского языка, Москва: Наука 2008.

Кончаревић, Ксенија. Савремена настава руског језика Београд. Славистичко друштво Србије, 2004.

Марковић, Александра. „Граматика у српским речницима” [В:] Рајна Драгићевић (ред.) Савремена српска лексикографија у теорији и пракси Београд: Чигоја 2014, 69-91.

Маројевић, Радмило. Граматика руског језика Београд: Завод за уџбенике и наставна средства, 1983.

Младеновић, Александар. Двестота годишњица књижице „Сало дебелога јера либо азбукопротрес" Јужнословенски филолог LXVI 2010, 311-324.

Павловић-Шајтинац, Маја. „Принципи конципирања школских речника” Филолог $162017,152-161$.

Пипер, Предраг. „О принципима уџбеничке лексикографије” Живи језици 1-4 1992, 27-41.

Рацковић, Никола. „Лексикографија - потреба стандарда” Библиографски вјесник 1-2-3 2006, 240-245.

Ристић, Стана. „Квалификатори у српској лексикографији” [В:] Рајна Драгићевић (ред.) Савремена српска лексикографија у теорији и пракси Београд: Чигоја 2014, 113-131.

Станковић, Богољуб. „О рекцијским разликама руских и српскохрватских глагола" Живи језици XVI 1-4 1974, 5-17.

Станковић, Богољуб. Лексикографски огледи Београд: Славистичко друштво Србије, 1999: 07-109 
Тошовић, Борисав. Преводна семантизација у двојезичном рјечнику (необјављена докторска дисертација) Београд 1992:83.

Тюрина, Лариса Г. «Современная типографика в учебном издании» [В:] С. Г. Антонова, А. А. Вархушев (ред.) Современная уиебная книга Москва: Московский государственный университет печати, 2004, 157-173.

\section{Речници}

Станковић, Богољуб. Речник руског језика: за основну школу. Београд: Завод за уџбенике и наставна средства. 1979.

Станковић, Богољуб. Школски руско-српскохрватски речник: средњи ниво учења. Београд: Завод за уџбенике и наставна средства, 1983.

Станковић, Богољуб. Руско-српски речник: за основну школу. Београд: Завод за уџбенике и наставна средства, 1999.

Станковић, Богољуб. Руско-српски и српско-руски речник: за основну школу. Београд: Завод за уџбенике и наставна средства, 2004.

Станковић, Богољуб. Руско-српски и српско-руски речник: за средњу школу. Београд: Завод за уџбенике, 2011.

Майя Павлович-Шайтинац

\section{ЛЕКСИКОГРАФИЧЕСКАЯ КОНЦЕПЦИЯ УЧЕБНЫХ СЛОВАРЕЙ БОГОЛЮУБА СТАНКОВИЧА}

\section{Резюме}

Статья посвящена анализу лексикографической концепции учебных словарей автора Б. Станковича. В процессе рассмотрения составляющих макрои микроструктуры данных словарей, способа их презентации и конструкции, прослеживается направленность автора на активизацию умении самостоятельной работы со словарем его пользователей, а тем самым и на обеспечение их лексикографической компетенции.

Ключевые слова: лексикография, макроструктура, микроструктура, продуктивные коммуникативные способности, лексикографическая компетенция 